\title{
Pertaining Factors on the Audit Quality: Ethical Evidence from Indonesia
}

\author{
Hajanirina Andrianantenaina \\ hajanirina@president.ac.id \\ Accounting Study Program, Faculty of Business \\ Universitas Presiden, Cikarang, Indonesia \\ Mila Austria Reyes \\ mila.reyes@president.ac.id \\ Accounting Study Program, Faculty of Business \\ Universitas Presiden, Cikarang, Indonesia
}

\begin{abstract}
This research attempts to investigate the audit quality based on the pertaining factors including ethical professional behavior, conflict of interest, audit fee that are mediated by religion and cognitive factor. The main issue we tend to discuss relies on the inconsistency of the literature on the audit quality but which ethics represented by the code principles with behavioral constuct prime over the premice. Using survey of 100 auditors from different background (seniority, firm image, and religious aspects); we found that not the ethical behavior matters but the conflict of interest upon the audit quality. Besides, auditor's fee also becomes a significant parameter of he audit quality. Cognitive factor is necessary for auditor to have best practice on the ethical aspect from the reasoning.
\end{abstract}

Keywords: audit fee, audit quality, conflict of interest, ethical professional behavior, religion

\begin{abstract}
Abstrak
Penelitian ini mencoba untuk menyelidiki kualitas audit berdasarkan faktor-faktor yang terkait termasuk perilaku profesional etis, konflik kepentingan, biaya audit yang dimediasi oleh agama dan faktor kognitif. Masalah utama yang akan dibahas terkait dengan ketidakkonsistenan literatur tentang kualitas audit, etika yang mana diwakili oleh prinsip-prinsip kode audit akan lebih utama daripada premis lain. Dengan menggunakan survei terhadap 100 auditor dari berbagai latar belakang (senioritas, citra perusahaan, dan aspek keagamaan); kami menemukan bahwa masalahnya bukanlah pada perilaku etis tetapi konflik kepentingan yang akan mempengaruhi kualitas audit. Selain itu, biaya auditor juga menjadi pengukuran signifikan terhadap kualitas audit. Faktor kognitif diperlukan agar auditor memiliki praktik terbaik pada aspek etika yang dibantu oleh pelanarannya.
\end{abstract}

Kata kunci: biaya audit, kualitas audit, konflik kepentingan, perilaku profesional etis, agama 


\section{INTRODUCTION}

Two groups of auditors mainly assure the firm's financial report validity. Both, independently certify through their opinion the report based on its quality. Issue on that independence arises as of example internal auditors are influenced by the firm's environmental condition including the organizational politic, culture, pressure and having less autonomy if compared to external auditors. For that, aretaic, teleic and deontic perspectives are adopted to analyze the internal auditor's ethics issue and found that moral will was not practically understood and even conflicted (Everett \& Tremblay, 2013). Besides, the cost associated to the non-compliance to the ethics involves "heavy" charge in the detriment of related stakeholders. Apart from the organizational evaluation on auditors' legitimacy, public perception starts questionning the ethical conduct since scandals go international alongside the globalization era (the case of Enron). Auditors hold important role to serve for the public interest, thus they are public figures of trust (Ardelean, 2013).

For the spread of audit scandals, it affects developed and developing countries including Indonesia. As reported by Dow et al. (2018), the case of WWM, Inc. represents the unethical problem that leads the firm in committing fraud towards the customers that needs credit loan. As for the case of Sri Lanka, a South Asian Association for Regional Cooperation (SAARC) member, the integrated reporting (IR) technology is still in the first stage that might have ethical value if not it becomes simply a mechanism as some companies are reluctant to internally integrated the system. As for the case of Greece, improvement on the code of ethics for audit profession seems blur until the public accusation on the profession increases by which the code is adjusted including some western ingredient. Besides, Mohamed and Habib (2013) discover that the audit quality in Egypt lacks independence of the auditor due to non practice of the code of ethics, the lack of organizational structure including the official license difficulties and the auditing standard enforcement. As for Sweeden, the audit quality depends on authorities obedience, the ethical norm enforcement through penalties and ethical environment enhancement. Besides, time budget pressure impacts on ethical culture as well (Svanberg \& Ohman, 2013). Among the main problem in the auditing profession (the quality of audit), is lack of independence triggered by the relationship between the director and auditor. Gap between what the public expect and what actually the quality of the auditor increases. Sometimes, the non intervention of the authorities may cause distortion on the quality that might worsened by the less support of auditors to the company as the case of Hong Kong (Yam \& Yam, 1993). Specifically for the Indonesian case, as altered by different remarkable regimes from Suharto, Habibie, Abdurrahman Wahid, Megawati, Yudhoyono and Jokowi administrations, political impact on the earnings management practice was found by Habib et al (2017). Firms tend to expropriate wealth through related parties' loans and practice earnings management to smooth that expropriation. Thus, it requires analysis on the audit quality in the mainland.

For all of these aspects, the auditor's role remain critical for the business sustainability since it might become two different sides (harmful/beneficial) for the business. Ethical behavior, fees and conflict of interest are different constructs but interelated. Code of ethics already established for auditors but the application in real work still needs to be investigated. For the money-talk side, the amount of fee added with the conflict of interest could generate behavioral displacement that endangers the quality of the opinion an auditor needs to be accountable.

Implementation and practice of ethics are required due to the problem of public trust as the citizen hopes and relies on auditor's moral behaviour as in Ardelen (2013). However, the rules and regulations focus the more on the standard and principles. Thus, ethics need to be set in the auditing 
culture. It encompasses the best practice, the lawful, right concept and well conducted manner to proceed for the audit work. It may impliy different result from different samples from different approach that ethics has effect on the audit quality.

Thus, this research will attempt to analyze the pertaining factors (ethics) towards the audit quality in Indonesia. Therefore, this research is expected to contribute to the extant literatures that lack consistence in the field, and will provides new insight for further investigation as well.

\section{LITERATURE REVIEW}

In the agency theory of Jensen and Meckling (1975), the social contract triggers the self interest optimalization for the agent to act contrarily towards the principal's wealth maximization. In the audting process, the fijudiciary compensation from the contract impacts on the auditor's personal behavior. The contract might involve between the low level of auditor staff and the junior auditor, the junior auditor to the senior auditor. Furthermore, the senior auditor to the general manager of the client. Self-interest has impact on the quality of the audit to the extent that if one of the agent perceive unfairness, it will lead to the important personal profit seeking act. Thus, the audit quality will be questionable.

The audit quality is searched through different angles from period to period from international scale to national one. Many factors are searched but not done thorughly in one context for a given country. Among others, audit quality depends on the political, psychological, professional, and environmental ties (Jeff \& Marie-Soleil, 2013; Habib et al , 2017). Besides, ethical code of conduct, audit standard, licence, authority involvement, budget preasure, ethical culture and ethic enforcement dictates the result of audit quality (Mohamed and Habib, 2013; Yam \& Yam, 1993; Svanberg \& Ohman, 2013).

Recently, the impacts of these factors (for the negative ones) resulted from the public untrust to the audit quality. They mostly worsen the independence of auditors. Public expectation and the actual result gap increases. Thus, auditors are viewed to not act for the public wealfare. Besides, company manifestation for unethical conducts appears in the form of earnings management, audit result manipulation (Enron), fraud and violation of ethical code.

The ethics is important and serves as the master counselor for an auditor to take decision upon the financial statement of a company. In practice, the existence of code of ethics helps the auditor to determine the limit of an action, to solve a situation that seems ambiguous and vague (Prasad, 2012). It sets then the ethical behaviour limit to which the decision maker (auditor) could refer to. For this case, if ethics predicts what is right and wrong known as the deontology consequentialism evaluates only the "right or wrong" based on the doer of the action and the consequence of that deed.

In the audit context, the quality of the audit depends on the value-linked (ethical) decision. Information needs to be verified and checked in accordance with the consistency of the organizations both external and internal ones. Thus, the quality provides for the stakeholder accountable, tranparent, and value-linked reports that enhances the public trust (Prasad, 2012).

Related to that audit quality, Sun and Cahan (2015) found for the case of China that audit quality depends on the auditor's personal characteristics including gender, education, tenure engagement, importance of the client, and the experience on auditing. Besides, audit fees and experience have positive relationship. Yet, the ethical values are not discussed. 
Similar to Sun and Cahan (2015) on gender impact upon audit quality, Al-Dharmanri and Chandren (2017) found for the case of Malaysia as well that women audit partner could assure the performance of the audit in terms of company profitability like earnings and equity book values. Thus, the reliability is improved. It is viewed that women auditor are risk averse possessing highl level of ethical behavior.

Authors recognized the shift in audit focus (illustrated for the internal auditor), that is the alteration of professionalism to rule. In fact, the profession is viewed as commercialization of the audit. It also primes the consulting over the auditing practice (Everett \& Tremblay, 2013). Thus, the quality of the audit ethically depends on the moral the auditor primes that is the professionalism. Since 1989, it was viewed that the era of unethical period prevailed. Related to that professionalism, objectivity and independence of the auditor are highly required, thus, self regulation primes. Besides, code of ethics serve important roles on the quality of the audit (Gavin \& Klinefelter, 1989).

Related to professionalism, Gunz and McCutcheon (1991) distinctly analyzed the relationship between conflict of interest in light with the auditor's independence. Auditor's independence is on of the most important principle that should be hold to safeguard the audit quality. Discussed through illustrations that independence and ethics are complementary. However, self interest blurs the relationship and it might become common practice that reduces the quality of audit increasing public untrust.

Personal behavior of each auditor is important for the quality of the service delivered. An auditor is a member of a team (both for internal auditors' as well as external ones). The position in the membership maintains impact on the workload. The audit committee determines then the work volume and tasks associated to serve a firm's demand. Experience, education, affection to the organization, personnal traits, religion and scepticism attitude feature the quality of the members. Audit committee then work for the firm. However, for Zhou et al. (2018) found insignificant relation between the characteristics of audit committee and firm perfomance.

Therefore, from the above theories and findings, hypotheses are formulated as follows:

$\mathrm{H}_{1}$ : Ethical personnal behavior has relationship with audit quality

$\mathrm{H}_{2}$ : Conflict of interest has negative relationship towards ethical behavior

$\mathrm{H}_{3}$ : Conflict of interest has negative relationship towards audit quality

$\mathrm{H}_{4}$ : Audit fee have relationship with audit quality

$\mathrm{H}_{5}$ : Congnitive factor on code of ethic mediate the relationship between personnal behavior towards audit quality

$\mathrm{H}_{6}$ : Congnitive factors on code of ethic mediate the relationship between conflict of interest towards audit quality.

$\mathrm{H}_{7}$ : Religion mediate the relationship between ethical personnal behavior and audit quality

Throughout the literature, independence, ethical behavior and audit quality are elaborated and will be tested for the evidence. Religion prevails as the majority of the Indonesian citizens hold a majority of a specific religion. Habib et al. (2018) stated as well that this construct is important on studying the Indonesian case in terms of audit ethical issues. It is hoped to moderate the relationship upon these factors. 


\section{Research framework}

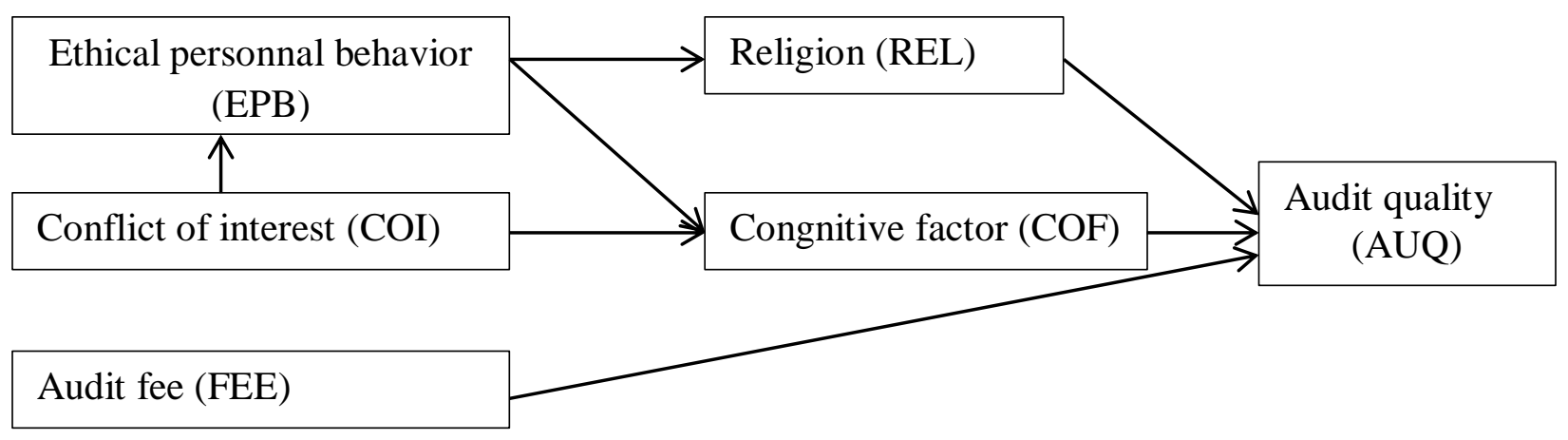

Figure 1. Research framework

\section{RESEARCH METHOD}

As derived from the above hypotheses, our constructs include the following latent variables:

\section{Explained constructs}

Audit quality

It is the result of the auditor's work on the firm's financial reports analysis and investigation. It implies as well the general analysed firm's trusted actual financial condition as well as management condition that are sourced from the auditor's crafted effort. It relies on the opinion the auditor decides upon the firm or organization's actual state. It is normally based on the auditor's perception on the real events occured in the company. This quality depends on how well the auditor perform his/her task.

\section{Exploratory constructs}

Ethical personnal behavior

This factor includes, self awareness, self consciousness, self estim, self interest, self confidence, and self regulation. Besides, ethical awarness, experience and scepticism are involving in this measurement.

External factors

Auditor's fee it is the compensation upon the auditor's accomplished given task. However, in in fact, another important construct needs to be searched. It is the conflict of interest form intern or external causes (intern-manager, extern-manger). Lrge, profitable clients were unwilling to engage an unknown accounting firm, so Gary was only able to attract smaller and riskier clients, Dow et al. (2018).

\section{Mediating}

We decide only to include the cognitive knowlege on code of ethics and religion as these involve cognitive and spiritual ties.

In these research, we conduct a survey with a purposive sampling technique by which employee having experience on audit is requested to fill the survei. We do not only consider the certified auditor but all who contribute to the quality of the audit reports. Due to the complexity of our construct relationship, we use structural equation modelling (SEM) using Smart-PLS since our sample is one hundred samples. 
Our questionnaire is designed enabling to measure the constructs. For practical reason, we use Indonesian language as our respondents are local auditors (see Appendix 1). To avoid bias, we do not include the construct name as in that appendix. Besides, we use positive and negative affirmation to avoid unawarness of the respondent while filling the questionnaire. The questionnaires are distributed via a link from Google form drive, mail, other people and through social media including Linked-In.

More than 250 respondents are targeted but only 100 samples are appropriate. We delete some of our questions that unable to measure the construct. We analyse the respondents' answers which indicate that they are aware, conscious, serious and attentive to the questions. However, there are some who ignore some elements of our questions, by which we need to delete.

\section{RESULT AND DISCUSSION}

\section{Descriptive Statistics}

Table 1. Desctiptive Statistics

\begin{tabular}{|c|c|c|c|}
\hline \multirow{2}{*}{$\begin{array}{l}\text { No } \\
1 \\
\end{array}$} & \multicolumn{3}{|c|}{ Demographic elements } \\
\hline & Gender & & \\
\hline & Male & Female & \\
\hline & $57 \%$ & $43 \%$ & \\
\hline 2 & Religion & & \\
\hline & Have a religion & $100 \%$ & \\
\hline 3 & Age & & \\
\hline & $\begin{array}{l}26-35 \text { years old } \\
46 \%\end{array}$ & $\begin{array}{l}36-55 \text { years old } \\
20 \%\end{array}$ & $\begin{array}{l}56-65 \text { years old } \\
34 \%\end{array}$ \\
\hline 4 & Firm & & \\
\hline & $\begin{array}{l}\text { Big } 4 \\
10 \%\end{array}$ & $\begin{array}{l}\text { Non-Big } 4 \\
90 \%\end{array}$ & \\
\hline 5 & Type & & \\
\hline & $\begin{array}{l}\text { External } \\
73 \%\end{array}$ & $\begin{array}{l}\text { Internal } \\
27 \%\end{array}$ & \\
\hline 6 & Education & & \\
\hline & S2 & S3 & \\
\hline & $94 \%$ & $6 \%$ & \\
\hline 7 & Tenure & & \\
\hline & $1-2 \mathrm{y}$ & $2-4 \mathrm{y}$ & $>12 y$ \\
\hline
\end{tabular}

Source: From the data processed

Based on Table 1, it shows that the gender is not significantly different in total $(57 \%$ to $43 \%$ for male favour) of the respondents. Thus, we do not search on the gender impact in this analysis. They all have a definite religion by which we quest from Islam, Catholics, Protestant, Buddhist, Hinduist and others. Religion is expected to have impacts on the auditors' behavior. 
Even though, the majority of the respondents are young, they are mature enough as $24 \%$ are already experienced in the work for more than 12 years. Besides, their education is high from Master to Doctor.

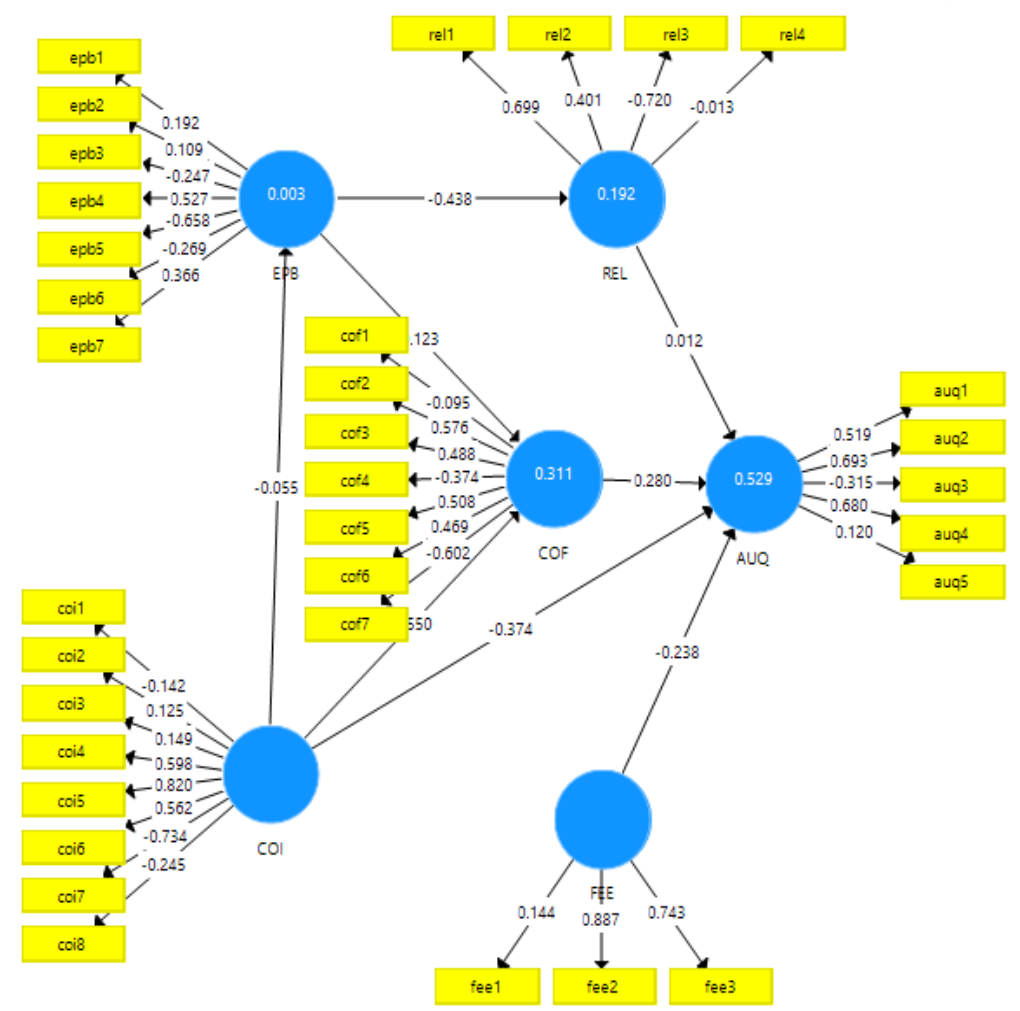

Figure 2. Diagram result of the test

Figure 2 shows the result from SmartPLS software for the SEM analysis. These indicators are sourced from the primary data of the questionnaire. It also displays the impacts of each construct to the main audit quality (AUQ).

Table 2. Test Results

\begin{tabular}{cccccc}
\hline Elements & Original sample & Sample mean & Sdv & t-stat & p-value \\
\hline $\mathrm{COF} \rightarrow$ AUQ & 0.280 & 0.256 & 0.136 & 2.052 & $0.041^{*}$ \\
$\mathrm{COI} \rightarrow$ AUQ & -0.374 & -0.336 & 0.197 & 1.901 & $0.058^{*}$ \\
$\mathrm{COI} \rightarrow \mathrm{COF}$ & -0.550 & -0.474 & 0.301 & 1.829 & $0.068^{*}$ \\
$\mathrm{COI} \rightarrow \mathrm{EPB}$ & -0.055 & -0.056 & 0.275 & 0.198 & 0.843 \\
$\mathrm{EPB} \rightarrow \mathrm{COF}$ & -0.123 & 0.040 & 0.189 & 0.650 & 0.516 \\
$\mathrm{EPB} \rightarrow \mathrm{REL}$ & -0.438 & -0.034 & 0.443 & 0.989 & 0.323 \\
$\mathrm{FEE} \rightarrow$ AUQ & -0.238 & -0.249 & 0.122 & 1.946 & $0.052^{*}$ \\
$\mathrm{REL} \rightarrow$ AUQ & 0.012 & -0.008 & 0.122 & 0.096 & 0.923 \\
$\mathrm{EPB} \rightarrow \mathrm{REL}$ & -0438 & -0.034 & 0.443 & 0.989 & 0.323 \\
$\mathrm{EPB} \rightarrow \mathrm{COF}$ & -0.123 & 0.040 & 0.189 & 0.650 & 0.516 \\
$\mathrm{COI} \rightarrow$ EPB & -0.055 & -0.056 & 0.275 & 0.198 & 0.843 \\
$\mathrm{COI} \rightarrow \mathrm{COF}$ & -0.550 & -0.474 & 0.301 & 1.829 & $0.068 * *$ \\
\hline
\end{tabular}


Based on these results (Figure 2 and Table 2); it is important to explain that it is not the ethical behavior that matters normally in practice. The conflict of interest has negative value and significant toward the audit quality. In real words, moslty, there is a negociation from the client and the accountant public firm. This negociation is normal, however, unethically, some cases occur that the opinion also is impacted. Normally, it is due to the fact that the client is loyal, the tenure is long, both firms become friends. The form of interest is evidenced by many authors including the client loyalty, the audited firms' beneficial sides (avoiding negative information for the firm that harms its image, its investor's trust).

Thus, our first hypothesis (H1) is not supported to the extend that ethical behavior is not the issue as in our sample $100 \%$ of them rely on the religion side even though it does not impact directly to the quality, it somehow forge the auditor's character, traits, attitude and behavior on the ethical part. This first hypothesis results from insignificant relationship between the ethical personnal behavior and the audit quality, that is surprisingly in line with the analysis made by Ardelean (2013) as follows:

"If the auditors are motivated in their ethical behaviour by an external coercing force, then they don't have a profound conscientiousness of their audit mission and might fall prey to cupidity and greed."

Thus, the driven factor (coercing force) in our result is the "greed" upon the remuneration and the other interests between the auditor and the audited firm (time budget constrait, audit fee and other interests (monetary and non monetary)). The auditor, despite the principle, the experience and the professionalism that are prioritized, temptation fades these ethics and morals to the detriment of the quality.

Table 3. Hypotheses Summary Results

\begin{tabular}{ll}
\hline Hypothesis & Result \\
\hline H1: Ethical personnal behavior has relationship with audit quality & Not supported \\
H2: Conflict of interest has negative relationship towards ethical behavior & Not supported \\
$\begin{array}{l}\text { H3: Conflict of interest has negative relationship towards audit quality } \\
\text { H4: Audit fee have relationship with audit quality }\end{array}$ & Supported \\
$\begin{array}{l}\text { H5: Congnitive factor on code of ethic mediate the relationship between } \\
\text { personnal behavior towards audit quality }\end{array}$ & Not supported \\
$\begin{array}{l}\text { H6: Congnitive factors on code of ethic mediate the relationship between } \\
\text { conflict of interest towards audit quality }\end{array}$ & Not supported \\
$\begin{array}{l}\text { H7: Religion mediate the relationship between ethical personnal behavior and } \\
\text { audit quality }\end{array}$ & Not supported \\
\hline
\end{tabular}

Besides, the mediating effect of cognitive and religion impacts are not significant. It indicates that only knowing the ethical codes is not what important. Its real practice primes over the cognitive aspect while conducting the result. Religion only impacts on the auditors intrinsic behavior but not on the quality of the opinion. However, religion forges the auditor's characters. Fee might have devastated role to the behavior deplacement of an employee including the auditor.

Furthermore, on the relationship between EPB to AUQ (H1), regulations is not enough to apply the moral, it comes to the auditor to apply ethics code. It is in line with Alexandra (2017), although the regulation on ethics prevail, its application depends on the auditor to maintain the public trust. It is in line with the fact that there is dilemma on the auditor's independence and the contract for the client by which what is ethical as "lawful" implies no non-audit service should be 
accepted (bookkeeping, accouting records, broker services, etc.). The independence is due to lack of ethical behavior that is derived from the contract of both parties. The ethical factor will fade when the independence is not absolute. Thus, normally, the audit quality is in danger, but in our research, we find that the EPB is not main factor to justify the quality of the audit. It is due to the fact that either the auditor relies on belief and avoid any unethical deeds because they are professional and skill full as based on our sample, on average their expertise and education are high.

As for COI to EPB (H2), the relationship is as expected that negative value indicates the opposite tendency for these constructs. In the presence of high conflict of interest, the auditor faces dilemma on what should be decided between the quality and the interest (internal, and external constraints). However, it is not significant statistically for our result since the auditors on average have long experience on such dilemma (see Table 1 on descriptive statistics, $24 \%$ of them have more than 12 years). In the presence of high professionalism, the auditor could manage choosing between the personnal interest, firm interest and the public trust interest. The longer the auditor get accustomed with these issues, the easier the decision is made. It might harm the relationship between supplier-customer but it has long life horizon. Thus, the relationship between conflict of interest and ethical behavior becomes insignificant as the auditor are driven by both positive and negative forces (positive forces: profesionnalism, experience focusing on standard, the enforced regulations and laws, for the negative forces: the "greeds" (pecuniary and non pecuniary aspects)).

As for the conflict of interest here, it is due to the fact that in practice, some of the auditors are influenced by the negociation and the audit tenure between both parties. Thus, conflict of interest has negative impacts on the audit quality. The higher that driven factor the less quality the opinion is. Therefore, the significant negative impact of COI to AUQ (H3) is supported. Besides, it is in line with Gunz and McCutcheon (1991) as the auditor might be affected as the interest is primed over.

Audit fee has relationship to the audit quality (H4) as it is in line with Ardelean (2013), and Gunz and McCutcheon (1991) on the negatie side as ethics might be lessed considered. However, the relationship from the result shows a negative one, indicating that while the audit fee decreases for a certain aspects, the quality increase to the extent that it has link with the presence of good/bad relationship between both parties. Besides, if profesionalism primes over the conflict of interest and the "greed" aspect, then with less fee (compared to the competing public firm), the quality is always met.

For the mediating effects (COF and REL, on $\mathrm{H} 5$ to $\mathrm{H} 7$ ), it reflects that in the presence of experience, the auditor avoid mistakes on the wrong use of values (religion) nor on the mere knowledge of the ethics code, but the standard as auditing process is a scientific approach.

\section{CONCLUSION}

In sum, we can conclude that the pertaining construct fee can be materialized in terms of estimating the audit quality. Ethical behavior represents a reliable measurement for the auditor's conduct however, only from cognitive aspect, it fades. In our quest, we unexpectedly find that religion and cognitive constructs unable to mediate the relationship with personal ethical behavior and conflict of interest. We suggest for that to enlarge the sample form all geographical area in Indonesia. Besides, other factors are needed to be analysed to improve the literature on auditor's 
quality. We are in line with Barbadillo et al. (2000), that it is still better to not have third parties to intervene in the auditor's profession as it might create another crisis.

\section{REFERENCES}

Alexandra, A. (2013). Auditors'ethics and their impact on public trust. Lumen International Conference Logos Universality Mentality Education Novelty (LUMEN 2013). 92, hal. 5560. Procedia - Social and Behavioral Sciences.

Ashbaugh, H. (2004). Ethical issues related to the provision of audit and non-audit services: evidence from academic research. Journal of Business Ethics, 52, 143-148.

Cahan, S. F., \& Sun, J. (2015). The effect of audit experience on audit fees and audit quality. Journal of Accounting, 30(1), 78-100.

Dedoulis, E. (2006). The code of ethics and the development of the auditing profession in Greece, the period of 1992-2002. Accounting Forum, 30, 155-178.

Dow, E. K., Watson, M. W., Shea, J. V., \& Kern, S. (2018). An accounting ethics case from multiple perspectives. Journal of Accounting Education.

Gavin, T. A., \& Klinefelter, D. S. (1989). Professional ethics and audit. Managerial Auditing Journal, 4(2), 24-28.

Gunarathne, N., \& Senaratne, S. (2017). Diffusion of integrated reporting in an emerging South Asian (SAARC) nation. Managerial Auditing Journal, 32(4/5), 524-548.

Habib, A., Muhammadi, H. A., \& Jiang, H. (2018). Political connections and related party transactions: Evidence from Indonesia. The International Journal of Accounting.

Jeff, E., \& Marie-Soleil, T. (2013). Ethics and internal audit: Moral will and moral skill in a heternonomous field. Critical Perspectives on Accounting.

Mohamed, D. M., \& Habib, H. M. (2013). Auditor independence, audit quality and the mandatory auditor rotation in Egypt. Education, Business and Society: Contemporary Middle Eastern Issues, 6(2), 116-144.

Prasad, V. H. (2012). Ethics and auditing: An international perspective. International Journal of Finance and Accounting, 1(4), 63-68.

Svanberg, J., \& Ohman, P. (2013). Auditors' time pressure:does ethical culture support audit quality? Managerial Auditing Journal, 28(7), 572-591.

Yam, S. C., \& Yam, W. P. (1993). Incorporating audit firms in Hong Kong: Issues and problems. Managerial Auditing Journal, 8(6), 3-13. 